\title{
Information Systems for New Students Assesment at Setia Bhakti Junior High School Using the Simple Additive Weighting (SAW) Method
}

\author{
Felisia Fransiska ${ }^{1}$, Yakub $^{2}$, \\ 1, 2 Buddhi Dharma University, Information System, Banten, Indonesia
}

\begin{tabular}{|c|c|}
\hline SUBMISSION TRACK & 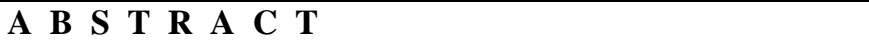 \\
\hline $\begin{array}{l}\text { Received } 20 \text { June } 2018 ; \\
\text { Revised } 20 \text { July } 2018 ; \\
\text { Accepted } 10 \text { September } 2018 ; \\
\text { Available online } 20 \text { September } 2018\end{array}$ & \multirow{5}{*}{$\begin{array}{l}\text { Technology has a big role in today's life, especially helping } \\
\text { the business process activities within a company or } \\
\text { organization, making the business process easier. For this } \\
\text { reason the creation of a new student admission system and } \\
\text { entrance examination in a high school, which affects the } \\
\text { speed and accuracy of the final grades in the process. The } \\
\text { method used is the Simple Additive Weighting (SAW) } \\
\text { method, which has more precise and accurate advantages } \\
\text { compared to other decision-making models, because its } \\
\text { ability to conduct an assessment is based on the value of } \\
\text { criteria and weighted preferences that have been determined. } \\
\text { The design and analysis of new student admissions and } \\
\text { entrance examination exams can help and overcome existing } \\
\text { problems. New student admission and admission test } \\
\text { programs have the advantage of being a computerized } \\
\text { student registration, conducting computer-based entrance } \\
\text { examination exams and can process data through the system } \\
\text { thereby reducing the risk of errors in making reports. }\end{array}$} \\
\hline KEYWORD & \\
\hline $\begin{array}{l}\text { New Student Assesment, Junior High School, } \\
\text { Simple Additive Weighting, }\end{array}$ & \\
\hline KORESPONDENSI & \\
\hline E-mail: felisiaf@yahoo.com & \\
\hline
\end{tabular}

\section{INTRODUCTION}

The development of computer technology is progressing along with the increasing needs of the community. The public is increasingly familiar with technology to make it easier to do various activities in life. Using a computer for registration will minimize the risk of data loss and the student candidate forms are arranged neatly, waits long for the results of the entrance examination and will make it easy for school administration staff to make a list of prospective students.

Utilizing computer technology in education will make it easier for school administration staff to make a list of prospective students. Therefore, we need a development of technology and information-based systems that can be understood and used by users [1]. Currently the Registration system is still running using the manual method. The problems faced at Setia Bhakti Junior High School are currently in the Administration and also the Principal's section, among others, the admission of new students requires a lot of paper which is partly wasted, management of data on admission of prospective students who have not computerized, there is no ranking report 
student test results. In the process of data and making reports relating to the admission of new students still use Microsoft Word and Microsoft Excel.

Based on the problem above, it is proposed that the student admission system be designed using the UML method and using the SAW method, Simple Additive Weighting is a decision making method by normalizing the matrix to a scale that can be considered, with data that has been collected and then made assessment criteria based on that data. By using the SAW method the results obtained will be seen clearly, so it can be determined by optimally the highest value and be ranked of the largest weight and also by the use of the SAW method in the new student admission system will minimize the bias of preference values [2]. The making of this student admission system uses the use of the VB.Net application, with a MySQL database [3] [4]. This system generates student grade rating reports.

\section{LITERATURES REVIEW}

In the research application for New Student Registration with the Selection System Using the Simple Additive Weighting (SAW) Method at Vocational High School Miftahul Huda Ciwaringin Using the SAW method in student selection system aims to accelerate and facilitate the selection of prospective new students [5].

The other research using Exponential Comparison Method (MPE) in the Scholarship Decision Support System for Student Achievement at XYZ Vocational School. Decision support system to determine the scholarship recipients of high achieving students with achievement, discipline, and attendance criteria. By applying the MPE method it can reduce costs [6].

Implementation of the SAW Method in Accepting New Students at Negeri 16 Senior High School Medan. SAW method that serves as an aid in making decisions in the selection process. The system ranks based on criteria, from the ranking results will be known prospective students declared passed or not, then the system will provide new school recommendations for prospective students who do not pass the selection by selecting the closest distance from their house [7].

\section{METHODS}

The Simple Additive Weighting method is often known as the weighted sum method. The basic concept of the Simple Additive Weighting method is to find the weighted sum of the performance ratings for each alternative on all attributes [8] [9]. The Simple Additive Weighting method requires the decision matrix normalization process (X) to a scale that can be compared with all available alternative ratings. The formula shown below:

Step 1: Normalization

Step 2: Looking for Maximum and Minimum Value

$$
\begin{array}{ll}
r_{i j}=\frac{X_{i j}}{M a x ~ X i j} & \text { for Benefit Attribut } \\
r_{i j}=\frac{\text { Min Xij }}{\text { Xij }} & \text { for Cost Attribut }
\end{array}
$$

where $i, j=1,2, \ldots n$

Step 3: calculate the Preference Value

$\mathrm{Vi}=\sum_{\mathrm{j}=1}^{\mathrm{n}} \mathrm{w}_{\mathrm{j}} \mathrm{r}_{\mathrm{ij}}$

Where Vi $=$ Preference Value

Vi value will be the result of alternative calculations.

Determination of Criteria taken based on the principal at Setia Bhakti Junior High School that is: 
C1 = Primary school Rapot Score

$\mathrm{C} 2$ = Primary school national exam scores

C3 = Active in the Organization

$\mathrm{C} 4=$ Written Test Value

C5 = Interview Test Score

\section{RESULT}

The criteria and weightings agreed with the school principal are shown in tables 1 to 5 .

\section{Table 1. Criteria Weighting}

\begin{tabular}{cc}
\hline Criteria & Weight \\
\hline C1 & 0.30 \\
C2 & 0.25 \\
C3 & 0.20 \\
C4 & 0.15 \\
C5 & 0.10 \\
\hline
\end{tabular}

Table 2. Primary School Rapot Score Weighting

\begin{tabular}{ccc}
\hline Value & Result & Score \\
\hline$<50$ & Very Low & 1 \\
$50-60$ & Low & 2 \\
$61-70$ & Middle & 3 \\
$71-85$ & High & 4 \\
$86-100$ & Very High & 5 \\
\hline
\end{tabular}

Table 3. Primary School National Exam Scores

\begin{tabular}{ccc}
\hline Value & Result & Score \\
\hline$<45$ & Very Low & 1 \\
$46-55$ & Low & 2 \\
$56-65$ & Middle & 3 \\
$66-75$ & High & 4 \\
$76-100$ & Very High & 5 \\
\hline
\end{tabular}

Table 4. Active in the Organization

\begin{tabular}{lcc}
\hline Value & Result & Score \\
\hline $1-6$ & Very Low & 1 \\
$7-12$ & Low & 2 \\
$13-18$ & Middle & 3 \\
$19-24$ & High & 4 \\
$25-30$ & Very High & 5 \\
\hline
\end{tabular}

Table 5. Interview Test Score

\begin{tabular}{ccc}
\hline Value & Result & Score \\
\hline$<50$ & Very Low & 1 \\
$50-60$ & Low & 2 \\
$61-70$ & Middle & 3 \\
$71-85$ & High & 4 \\
$86-100$ & Very High & 5 \\
\hline
\end{tabular}

After get the weighting, in this case using 3 students for calculations:

Table 6. Students Scoring

\begin{tabular}{lccccr}
\hline Students & C1 & C2 & C3 & C4 & C5 \\
& $\mathbf{0 . 3 0}$ & $\mathbf{0 . 2 5}$ & $\mathbf{0 . 2 0}$ & $\mathbf{0 . 1 5}$ & $\mathbf{0 . 1 0}$ \\
\hline Cecilia & 4 & 4 & 2 & 3 & 4 \\
Floren & 4 & 4 & 2 & 4 & 4 \\
Febby & 3 & 4 & 2 & 4 & 3 \\
\hline
\end{tabular}

After the student scoring, start to calculate normalization with the formula, five criterias above is benefit $(+)$.

$\mathrm{r}_{11}=\frac{\mathrm{Xij}}{\operatorname{Max} \mathrm{Xij}}=\frac{4}{4}=1$

calculate with the same formula for $r_{12}-r_{35}$

Table 7. Normalization Students Scoring

\begin{tabular}{lccccc}
\hline Students & C1 & C2 & C3 & C4 & C5 \\
& $\mathbf{0 . 3 0}$ & $\mathbf{0 . 2 5}$ & $\mathbf{0 . 2 0}$ & $\mathbf{0 . 1 5}$ & $\mathbf{0 . 1 0}$ \\
\hline Cecilia & 1 & 1 & 1 & 0.75 & 1 \\
Floren & 1 & 1 & 1 & 1 & 1 \\
Febby & 0.75 & 1 & 1 & 1 & 0.75 \\
\hline
\end{tabular}

After get the normalization result, start to calculate the Preference Value.

$$
\begin{aligned}
\mathrm{Vi}= & \sum_{\mathrm{j}=1}^{\mathrm{n}} \mathrm{w}_{\mathrm{j}} \mathrm{r}_{\mathrm{ij}} \\
\mathrm{V}_{1}= & (0.3 * 1)+(0.25 * 1)+(0.20 * 1)+ \\
& (0.15 * 0.75)+(0.10 * 1) \\
= & 0.9625
\end{aligned}
$$

Preference Value result are follows: 
Table 8. Normalization Students Scoring

\begin{tabular}{|c|c|c|c|c|c|c|}
\hline Students & $\begin{array}{c}\text { C1 } \\
0.30\end{array}$ & $\begin{array}{c}\mathrm{C} 2 \\
0.25\end{array}$ & $\begin{array}{c}\text { C3 } \\
0.20 \\
\end{array}$ & $\begin{array}{c}\text { C4 } \\
0.15\end{array}$ & $\begin{array}{c}\text { C5 } \\
0.10\end{array}$ & P.V \\
\hline Cecilia & 0.30 & 0.25 & 0.20 & 0.11 & 0.10 & 0.9625 \\
\hline Floren & 0.30 & 0.25 & 0.20 & 0.15 & 0.10 & 1.0000 \\
\hline Febby & 0.22 & 0.25 & 0.20 & 0.15 & 0.07 & 0.9000 \\
\hline
\end{tabular}

Make a rank from Preference Value table 8. Table 9. Result

\begin{tabular}{ccc}
\hline Value & P.V & Rank \\
\hline Cecilia & 0.9625 & 2 \\
Floren & 1.0000 & 1 \\
Febby & 0.9000 & 3 \\
\hline
\end{tabular}

The student pass the test is Floren, Cecilia, and the last is Febby.

\section{CONCLUSION}

Based on an analysis of the Assesment system at Setia Bhakti Junior High School, the conclusions as follows:

1. This system, can produce reports on the entrance test scores along with the ranking of grades from prospective students.

2. This system, can reduce the use of excess paper and the risk of human error.

\section{REFERENCES}

[1] Yakub, (2012). Pengantar Sistem Informasi. Yogyakarta: Graha Ilmu.

[2] Kusrini, (2007). Konsep dan Aplikasi Sistem Pendukung Keputusan, Andi, Yogyakarta.

[3] Anhar, (2010). Panduan Menguasai PHP dan Mysql. Jakarta: Media Kita.

[4] Konixbam, (2009). Aplikasi Dekstop Menggunakan VB. Net, Surabaya.

[5] Magdalena Lena, Rachman Abdul. 2017. Aplikasi Pendafaran Siswa Baru Dengan

SistemSeleksi Menggunakan Metode Simple Additive Weighting (SAW) Pada SMK Miftahul Huda Ciwaringin. Jurnal Digit. (hlm, 38-49).

[6] Borman Indra Rohmat, Helmi Fauzi. 2018. Penerapan Metode Perbandingan Eksponensial (MPE) Dalam Sistem Pendukung Keputusan Penerima Beasiswa Siswa Berprestasi Pada SMK XYZ. CESS (Journal of Computer Engineering System and Science). (hlm, 17-22).

[7] Setiawan Adil. 2017. Implementasi Metode Saw Dalam Penerimaan Siswa Baru Pada SMA Negri 16 Medan. Jurnal Riset Sistem Informasi Dan Teknik Informatika. (hlm, 95$103)$.

[8] Dicky Nofriansyah, (2014). Konsep Data Mining vs Sistem Pendukung Keputusan”. Edisi I. Yogyakarta.

[9] B. Daniawan, "Evaluation of Lecturer Teaching Performance Using AHP and SAW Methods", bt, vol. 1, no. 2, pp. 30-39, Dec. 2018.

[10]Kurnia, Y., Isharianto, Y., Giap, Y. C., \& Hermawan, A. (2019, March). Study of application of data mining market basket analysis for knowing sales pattern (association of items) at the O! Fish restaurant using apriori algorithm. In Journal of Physics: Conference Series (Vol. 1175, No. 1, p. 012047). IOP Publishing. 


\section{BIOGRAPHY}

Felisia Fransiska, Graduated from the Information Systems Study Program (S1) in the academic concentration of Information Technology at 2019.

Yakub, Lecturer at Information System Study Program of Buddhi Dharma University, Tangerang. Graduates S1 Information System STMIK Widuri Jakarta, 2002, S2 Master Computer Eresha School of Information Technology, 2005, S2 Master of Management of Budi Luhur University, 2008, S3 Doctoral University of Islam Nusantara Bandung, 2014. 
FIRST AUTHOR / JURNAL TECH-E - VOL. X. NO. X(XXXX) 